\title{
DESIGN AND FORMULATION DEVELOPMENT OF FAST-DISSOLVING TABLETS OF IBUPROFEN USING NOVEL NATURAL SUPERDISINTEGRANT
}

\author{
CHANDRA SEKHAR NAIK D ${ }^{1 *}$, BHARATHI A ${ }^{1}$, BASAVESWARA RAO MV ${ }^{2}$ \\ ${ }^{1}$ Department of Pharmaceutics, K.V.S.R. Siddhartha College of Pharmaceutical Sciences, Vijayawada, Andhra Pradesh, India. ${ }^{2}$ Department \\ of Chemistry, Krishna university, Machilipatnam, Andhra Pradesh, India. Email: chandu.desavath@gmail.com
}

Received: 28 August 2019, Revised and Accepted: 04 October 2019

\section{ABSTRACT}

Objective: The objective of the study was to evaluate Ocimum gratissimum mucilage as a novel superdisintegrant in the formulation of fast-dissolving tablets (FDT) of Biopharmaceutical Classification System-II drug (Ibuprofen) employing a $2^{3}$ factorial design.

Methods: 0 . gratissimum mucilage was extracted by seeds and it was subjected to physical, chemical, and micrometric studies were evaluated. To establish FDT of ibuprofen with 0 . gratissimum mucilage as a superdisintegrants in different ratios using direct compression method employing $2^{3}$ factorial design. All the formulation tablets were evaluated pre-compression and post-compression parameters like dissolution efficiency (DE\%) percent of drug dissolved at 5 min.

Results: The mucilage was to be found fine, free-flowing crystalline powder, and excellent swelling nature in all suitable solvents and buffers. The Fourier transform infrared and differential scanning calorimetry studies were indicated to no interactions between ibuprofen and 0 . gratissimum mucilage. All the FDT formulated employing novel mucilage shows good quality with regard drug content $(98.05 \pm 0.31-99.39 \pm 0.54)$, hardness (3.6$4 \mathrm{~kg} / \mathrm{sq} . \mathrm{cm})$, and friability (0.12-0.15\%). The optimized formulation batch shows less disintegrant time (30 \pm 0.06$)$. In vitro wetting time was less (i.e., $90 \mathrm{~s}$ ) in optimized formulation F2. The water absorption ratio of the formulated tablets was found to be in the range of $99 \pm 0.56$. The cumulative drug dissolved in the optimized formulation F2 was found to be $99 \%$ in $10 \mathrm{~min}$.

Conclusion: 0 . gratissimum mucilage was found to be a novel superdisintegrant which enhanced the $\mathrm{DE}$ when combined with crospovidone and croscarmellose sodium; hence, it could be used in the formulation of FDT to provide immediate release of the contained drug within 5 min.

Keywords: Optimization, Fast dissolving, Superdisintegrant.

(C) 2019 The Authors. Published by Innovare Academic Sciences Pvt Ltd. This is an open access article under the CC BY license (http://creativecommons. org/licenses/by/4. 0/) DOI: http://dx.doi.org/10.22159/ajpcr.2019.v12i12.35505

\section{INTRODUCTION}

Oral routes of drug administration have a wide acceptance of up to $50-60 \%$ of the total dosage form. Fast-dissolving tablets (FDTs) are solid dosage form containing indicated substances that disintegrate rapidly, usually within few seconds when placed on tongue requiring additional water to facilitate swallowing. FDTs offer great advantages for the patients having difficulty in swallowing. The elderly constitute a major portion of today's population mainly because of the increased life span of individuals. Physiological and neurological conditions, such as dysphasia, a risk of choking, and hand tremors are leading causes of patient non-compliance in the self-administration of conventional solid oral dosage forms [1-3]

FDT formulation provides sufficient strength, quick disintegration/ dissolution in the mouth without water, rapid dissolution, and absorption of the drug, which will produce the quick onset of action. Pre-gastric absorption of FDTs can result in improved bioavailability and as a consequence of reduced dose. Various techniques can be used to formulate FDT. Direct compression one of the techniques which need for a particular purpose the inclusion of super disintegrate or highly water-soluble excipients into the formulation to reach fast tablet disintegration. Direct compression does not require the use of water or heat during the formulation procedure and is the ideal method for moisture and heat-liable medication.

The present investigation deals with an attempt of a systematic formulation approach for optimization of ibuprofen FDT employing Ocimum gratissimum mucilage, croscarmellose sodium, and crospovidone as superdisintegrants. A $2^{3}$ factorial design was applied to investigation the main and interaction effects of the three formulation variables, i.e., O gratissimum mucilage (A), croscarmellose sodium (B), and crospovidone (C) in each case to find the formula with less disintegration time and more dissolution efficiency (DE) $5 \mathrm{~min}$ and to permit arbitrary selection of tablets with immediate release of drug within 5 min [4].

\section{MATERIALS AND METHODS}

\section{Materials}

Ibuprofen pure drug obtained from Yarrow chemicals Mumbai. Mannitol, sodium and croscarmellose sodium were obtained from Yarrow chem. products, Mumbai. Microcrystalline cellulose was bought from Qualigens Fine Chemicals, Mumbai. Talc and magnesium stearate was obtained from Molychem, Mumbai.

\section{Isolation of 0 . gratissimum mucilage (a novel disintegrate)}

The seeds of $O$. gratissimum were soaked for $12 \mathrm{~h}$ in distilled water and then added to a blender to separate mucilage from seeds. After blending for $15 \mathrm{~min}$, the mass was passed through eight folds of muslin cloth. The mucilage was precipitated from the filtrate by adding three parts of acetone $(75 \%)$ to the mucilage. The powder was weighed to calculate the yield after drying at $45^{\circ} \mathrm{C}$ for $6 \mathrm{~h}$ [5].

Characterization of $O$. gratissimum mucilage (a novel disintegrate) The 0 . gratissimum mucilage prepared was evaluated for the following [6,7].

\section{Solubility}

O. gratissimum mucilage solubility was tested in various solvents such as distilled water, aqueous buffers of $\mathrm{pH} 1,2,3,4$, and 6 mentioned in 
IP and organic solvents such as alcohol, dichloromethane, chloroform, acetone, and petroleum ether.

$p H$

The $\mathrm{pH}$ of $1 \% \mathrm{w} / \mathrm{v}$ slurry was measured by $\mathrm{pH}$ meter

Melting point

The melting point was determined using melting point apparatus.

Viscosity

The viscosity of $1 \%$ dispersion in water was measured using Ostwald viscometer.

\section{Swelling index}

Mucilage powder (200 mg) was added to $10 \mathrm{ml}$ of water and light liquid paraffin taken in two different graduated test tubes and mixed. The dispersion in the tubes was allowed to stand for $12 \mathrm{~h}$. The volumes of the sediment in the tubes were recorded. The swelling index (\%) of the material was calculated as follows.

$$
\begin{aligned}
& \text { SI }=\frac{\text { Volume of sediment in water }-}{\text { Volume of sediment in light liquid paraffine }} \times 100
\end{aligned}
$$

SI = Swelling index

\section{Test for gelling property}

Mucilage prepared was evaluated for their gelling property by heating a $7 \% \mathrm{w} / \mathrm{v}$ dispersion of each in the water at $100^{\circ} \mathrm{C}$ for $30 \mathrm{~min}$

Particle size

Particle size analysis was done by sieving using standard sieves.

\section{Density}

Density (g/cc) was determined by the liquid displacement method using benzene as liquid.

Bulk density

Both loose bulk density (LBD) and tapped bulk density (TBD) were determined by transferring the accurately weighed amount of sample in $50 \mathrm{ml}$ measuring cylinder, measured the volume of packing and tapped 50 times on a plane surface and tapped volume of packing recorded and LBD and TBD calculated by following formula [8].

$$
\begin{aligned}
& \mathrm{LED}=\frac{\text { Mass of powder }}{\text { Volume of packing }} \\
& \mathrm{TBD}=\frac{\text { Mass of powder }}{\text { Volume of packing }}
\end{aligned}
$$

LBD = Loose bulk density

TBD $=$ Tapped bulk density

\section{Percentage compressibility index}

The percentage compressibility of the powder mixed was determined by Carr's compressibility index calculated by the following formula [9].

$$
\% \text { Carr's index }=\frac{\mathrm{TBD}-\mathrm{LBD}}{\mathrm{TBD}} \times 100
$$

TBD = Tapped bulk density

\section{Angle of repose}

The frictional forces in loose powder or granules can be measured by the angle of repose. This is the maximum angle possible between the surface of a mass of powder or granules and the horizontal plane. The angle of repose is calculated $[8,9]$

$$
\begin{gathered}
\tan \theta=\frac{h}{r} \\
\theta=\tan ^{-1} \frac{h}{r}
\end{gathered}
$$

$\theta=$ angle of repose; $h=$ height of pile; $r=$ radius of pile.

\section{Fourier transform infrared (FTIR) spectroscopy}

FTIR spectra of mucilage were recorded on samples prepared in potassium bromide (KBr) disks using a FTIR (Tokyo, Japan). The scanning range was $500-4000 \mathrm{~cm}^{-1}$. Samples were mixed with $(\mathrm{KBr})$ to form disks by means of a hydrostatic press at 6-8 tons pressure.

\section{Differential scanning calorimetry (DSC)}

DSC therm 0 . gratissimum rams of ibuprofen and their mixtures (1:1) with 0 . gratissimum were recorded on PerkinElmer Thermal Analyzer samples (2-5 $\mathrm{mg}$ ) were sealed into aluminum pans and scanned at a

\begin{tabular}{|c|c|c|c|c|c|c|c|c|}
\hline $\begin{array}{l}\text { Ingredients } \\
\text { (mg/tablet) }\end{array}$ & F1 & F2 & F3 & F4 & F5 & F6 & F7 & F8 \\
\hline Ibuprofen & 200 & 200 & 200 & 200 & 200 & 200 & 200 & 200 \\
\hline $\begin{array}{l}\text { Ocimum } \\
\text { gratissimum }\end{array}$ & - & 25 & - & 25 & - & 25 & - & 25 \\
\hline $\begin{array}{l}\text { Croscarmellose } \\
\text { sodium }\end{array}$ & - & - & 25 & 25 & - & - & 25 & 25 \\
\hline Crospovidone & - & - & - & - & 25 & 25 & 25 & 25 \\
\hline Mannitol & 30 & 55 & 55 & 30 & 55 & 30 & 30 & 5 \\
\hline MCC & 250 & 200 & 200 & 200 & 200 & 200 & 200 & 200 \\
\hline Talc & 10 & 10 & 10 & 10 & 10 & 10 & 10 & 10 \\
\hline $\begin{array}{l}\text { Magnesium } \\
\text { stearate }\end{array}$ & 10 & 10 & 10 & 10 & 10 & 10 & 10 & 10 \\
\hline Total & 500 & 500 & 500 & 500 & 500 & 500 & 500 & 500 \\
\hline
\end{tabular}
heating rate of $10^{\circ} \mathrm{C} \mathrm{min}{ }^{-1}$ over a temperature range $30-350^{\circ} \mathrm{C}$

\section{Preparation of ibuprofen FDT}

The tablets were prepared by direct compression method employing $2^{3}$ factorial design in which three independent variables

Table 1: Formulae of ibuprofen fast-dissolving tablets employing Ocimum gratissimum mucilage

MCC: Microcrystalline cellulose

Table 2: Evaluation of physicochemical proprieties for Ocimum gratissimum mucilage

\begin{tabular}{ll}
\hline Parameters & Ocimum gratissimum \\
\hline $\begin{array}{l}\text { Solubility studies } \\
\text { Water and all aqueous }\end{array}$ & $\begin{array}{l}\text { Slightly soluble in cold water and hot } \\
\text { water, form in viscous colloidal solution } \\
\text { and organic solvents }\end{array}$ \\
$\begin{array}{ll}\text { solvents } \\
\text { pH studies }\end{array}$ & 7.6 \\
Phytochemical tests & Pass \\
Molisch test & \\
Ruthenium test & Pass \\
Iodine test & Fail \\
Melting point & $203^{\circ} \mathrm{C}$ \\
Swelling index & $100 \%$ \\
Test for gelling property & Particle swelling \\
Density & $0.30 \mathrm{~g} / \mathrm{cc}$ \\
Tapped density & $0.48 \mathrm{~g} / \mathrm{cc}$ \\
Compressibility index & 0.309 \\
Hausner's ratios & 1.60 \\
Particle size & $152 \mu \mathrm{m}$ \\
Angle of repose & $25^{\circ}$ \\
\hline *SD standard deviation from $\mathrm{mean} \mathrm{n}=3$
\end{tabular}


(superdisintegrants, i.e., O. gratissimum [A], croscarmellose sodium [B], and crospovidone $[\mathrm{C}]$ ) and one dependent variable (DE in $5 \mathrm{~min}$ ) were selected. The composition of formulation is shown in Table 1 for $O$. gratissimum (A), the lower level, i.e., $0 \%$ concentration and upper level, i.e., $5 \%$ concentration. For croscarmellose sodium (B) and crospovidone (C), the lower level is zero concentration and higher level, i.e., 5\% concentration. For uniformity in particle size, each ingredient was passed through \# 100 mesh sized screen before mixing. O. gratissimum, croscarmellose sodium, crospovidone, mannitol, and microcrystalline cellulose were accurately weighed and mixed using mortar and pestle, and the added to ibuprofen. Finally, talc and magnesium stearate was added to the powder mixture $[10,11]$.

\section{Evaluation of ibuprofen FDT}

Hardness test

Hardness indicates the ability of a tablet to withstand mechanical shocks while handling. The hardness of the tablet was determined using Monsanto Hardness Tester and expressed in $\mathrm{kg} / \mathrm{cm}^{2}[12,13]$.

\section{Uniformity of weight}

Weight variation test was done with 20 tablets. It is the individual variation of the tablet weighed from the average weight of 20 tablets.

Friability

The friability of tablets was measured using a Roche friabilator. Tablets were rotated at $25 \mathrm{rpm}$ for $4 \mathrm{~min}$ or up to 100 revolutions. The tablets were then reweighed after removal of fines, and the percentage of weight loss was calculated [14].

$$
\mathrm{F}=\frac{100 \times \mathrm{W}(\text { initial })-\mathrm{W}(\text { final })}{\mathrm{W}(\text { initial })}
$$

\section{Drug content uniformity}

For content uniformity, ten tablets were weighed and powdered a quantity of powder equivalent to $10 \mathrm{mg}$ of ibuprofen was extracted into pH 1.2 HCL buffer and filtered. The ibuprofen content was determined by measuring the absorbance spectrophotometrically at $205 \mathrm{~nm}$ after appropriate dilution with $\mathrm{pH} 1.2 \mathrm{HCL}$ buffer. The drug content was calculated as an average of three determinations [15].

\section{Wetting time}

The wetting time of tablets was measured by placing five circular tissue papers in a Petri dish of $0.10 \mathrm{~m}$ in diameter. $10 \mathrm{ml}$ of water containing a water-soluble dye (amaranth) was added to the Petri dish. A tablet was carefully placed on the tissue paper. The time required for water to reach the upper surface of the tablet was noted as wetting time [16].

\section{Water absorption ratio}

A piece of tissue paper folded was kept in a small Petri dish to which $6 \mathrm{ml}$ of water was added. A tablet was kept on the tissue paper and allowed to completely wet. The wetted tablet was then weighed. Water absorption ration $\mathrm{R}$ was determined using the following equation [17-19].

$$
\mathrm{R}=\frac{100(\mathrm{Wd}-\mathrm{We})}{\mathrm{We}}
$$

Where,

Wd $=$ Tablet weight after water absorption

We $=$ Tablet weight before water absorption

\section{In vitro disintegration time}

Disintegration time for FDTs was determined using United States Pharmacopeia (USP) disintegration apparatus $0.1 \mathrm{~N} \mathrm{HCl}$ buffer. The volume of medium was $900 \mathrm{ml}$ and the temperature was $37 \pm 0.2^{\circ} \mathrm{C}$. The time in seconds taken for complete disintegration of the tablet with no palatable mass remaining in the apparatus was measured [19].

\section{In vitro dissolution studies}

In vitro dissolution rate study of ibuprofen FDT was performed using eight-stage dissolution test apparatus (lab India) fitted with paddles $(50 \mathrm{rpm})$ at $37 \pm 0.5^{\circ} \mathrm{C}$, using $\mathrm{pH} 7.2$ phosphate buffer $(900 \mathrm{ml})$ as a dissolution media. At the predetermined time intervals, $5 \mathrm{ml}$ samples were withdrawn, filtered through a $0.45 \mu$ membrane filter, diluted, and assayed at $221 \mathrm{~nm}$ using an analytical technology 0 . gratissimum Eli co SL 218 Ultraviolet/visible double beam spectrophotometer. The cumulative percentage release was calculated using standard absorbance from the calibration curve. All the dissolution experiments were conducted in triplicate $(n=3)[20,21]$.

\section{RESULTS AND DISCUSSION}

The isolation of 0 . gratissimum mucilage was found to be fine, freeflowing good swallowing powder. The physical and micrometric properties of the 0 . gratissimum mucilage are summarized in Table 2. It was insoluble in aqueous solvents and insoluble in organic solvents tested (methanol, petroleum ether, dichloromethane, and chloroform). The $\mathrm{pH}$ of $0.1 \%$ aqueous dispersion was found to be $7.62 \pm 0.001$.

O. gratissimum mucilage exhibited good swelling in water. The swelling index was found to be $100 \% \pm 0.003 \%$, indicating that it is suitable for superdisintegrant. All micrometric properties indicated good flow properties needed manufacturing tablets. The density of 0 . gratissimum mucilage was found to be $0.3012 \pm 0.0004 \mathrm{~g} / \mathrm{cc}$. The angle of repose and compressibility index showed good flow properties of 0 . gratissimum mucilage.

The FTIR spectrum of 0 . gratissimum mucilage is shown in Figs. 1-4. The presence of peaks absorption at $1434.10 \mathrm{~cm}^{-1}$ characteristic peak of ester, so from FTIR studies, it was concluded that 0 . gratissimum mucilage (ester) was formed when mucilage was allowed to react with formic acid. The DSC studies are shown in Fig. 4 of 0 . gratissimum mucilage showed characteristic peaks, which indicates that the structure is slightly crystalline. As the 0 . gratissimum mucilage was slightly fine powder and it had got all the characteristics of superdisintegrants, it was concluded that 0 . gratissimum mucilage can be used as novel superdisintegrant in the formulation of FDT.

Table 3: Physical properties: Hardness, friability drug content of ibuprofen fast-dissolving tablets prepared by direct compression

\begin{tabular}{|c|c|c|c|c|c|}
\hline Formulation & $\begin{array}{l}\text { Hardness } \\
\left(\mathrm{kg} / \mathrm{cm}^{2}\right) \mathrm{n} \pm S D\end{array}$ & $\begin{array}{l}\text { Friability } \\
(\%) n \pm S D\end{array}$ & $\begin{array}{l}\text { Drug Content } \\
(\mathrm{mg} / \mathrm{tab}) \mathrm{n} \pm \mathrm{SD}\end{array}$ & $\begin{array}{l}\text { Disintegration Time } \\
\text { (s) } n \pm S D\end{array}$ & $\begin{array}{l}\text { Water absorption ratio } \\
(\%) \mathrm{n} \pm \mathrm{SD}(\%)\end{array}$ \\
\hline $\mathrm{F} 1$ & $3.6 \pm 0.04$ & $0.14 \pm 0.021$ & $98.05 \pm 0.31$ & $1648 \pm 0.02$ & $20 \pm 0.01$ \\
\hline $\mathrm{F} 2$ & $3.5 \pm 0.06$ & $0.13 \pm 0.019$ & $99.85 \pm 0.65$ & $30 \pm 0.06$ & $99 \pm 0.56$ \\
\hline F3 & $3.7 \pm 0.07$ & $0.14 \pm 0.016$ & $99.23 \pm 0.58$ & $37 \pm 0.08$ & $71 \pm 0.37$ \\
\hline F4 & $3.7 \pm 0.02$ & $0.12 \pm 0.013$ & $98.94 \pm 0.61$ & $43 \pm 0.09$ & $79 \pm 0.94$ \\
\hline F5 & $3.9 \pm 0.06$ & $0.12 \pm 0.015$ & $99.46 \pm 0.89$ & $41 \pm 0.08$ & $68 \pm 0.61$ \\
\hline F6 & $3.8 \pm 0.03$ & $0.13 \pm 0.024$ & $98.04 \pm 0.18$ & $39 \pm 0.04$ & $86 \pm 0.38$ \\
\hline F8 & $3.6 \pm 0.05$ & $0.13 \pm 0.034$ & $99.39 \pm 0.54$ & $29 \pm 0.57$ & $100 \pm 0.21$ \\
\hline
\end{tabular}
method involving mannitol as a diluents

SD Standard Deviation from mean $n=3$ 
Table 4: ANOVA of percentage dissolved in 5 min of ibuprofen fast-dissolving tablets formulated employing Ocimum gratissimum

\begin{tabular}{|c|c|c|c|c|c|}
\hline Source of variation & d.f & S.S & M.S.S & Variance ratio & Result \\
\hline Replicates & 2 & 0.02 & 0.01 & 0.5 & $\mathrm{p}>0.05$ \\
\hline Treatments & 7 & 3475.21 & 496.75 & 2408.5 & $\mathrm{p}<0.05$ \\
\hline o. gratissimum (A) & 1 & 3325.20 & 3325.20 & 2408.5 & $\mathrm{p}<0.05$ \\
\hline Crospovidone (B) & 1 & 178.25 & 178.25 & 2473.72 & $\mathrm{p}<0.05$ \\
\hline O. gratissimum+crospovidone $(\mathrm{AB})$ & 1 & 435.67 & 435.67 & 3378.99 & $\mathrm{p}<0.05$ \\
\hline Croscarmellose sodium (C) & 1 & 1448.58 & 1448.58 & 2837.7 & $\mathrm{p}<0.05$ \\
\hline O. gratissimum+croscarmellose sodium (AC) & 1 & 854.26 & 854.26 & 2924.1 & $\mathrm{p}<0.05$ \\
\hline O. gratissimum+crospovidone+croscarmellose sodium (ABC) & 1 & 450.25 & 450.25 & 3353.7 & $\mathrm{p}<0.05$ \\
\hline Error & 14 & & 0.02 & - & - \\
\hline Total & 23 & - & - & - & - \\
\hline
\end{tabular}

*SD: Standard deviation from mean, $n=3, p<0.05$ indicates significance; $p>0.05$ indicates non-significance, d.f: Degree of freedom *S.S: Sum of square *M.S.S: Mean Sum of Squares, ANOVA: Analysis of variance. O. gratissimum: Ocimum gratissimum

Table 5: ANOVA of percentage of water absorption ibuprofen fast-dissolving tablets formulated employing 0 . gratissimum

\begin{tabular}{|c|c|c|c|c|c|}
\hline Source of variation & d.f & S.S & M.S.S & Variance ratio & Result \\
\hline Replicates & 2 & 0.02 & 0.01 & 0.5 & $\mathrm{p}>0.05$ \\
\hline Treatments & 7 & 4132.0 & 590.29 & 2408.5 & $\mathrm{p}<0.05$ \\
\hline o. gratissimum (A) & 1 & 8.02 & 8.02 & 2408.5 & $\mathrm{p}<0.05$ \\
\hline Crospovidone (B) & 1 & 72.56 & 72.56 & 2473.72 & $\mathrm{p}<0.05$ \\
\hline O. gratissimum+Crospovidone (AB) & 1 & 338.25 & 338.25 & 3378.99 & $\mathrm{p}<0.05$ \\
\hline Croscarmellose sodium (C) & 1 & 760.35 & 760.35 & 2837.7 & $\mathrm{p}<0.05$ \\
\hline O. gratissimum+Croscarmellose sodium (AC) & 1 & 12.50 & 12.50 & 2924.1 & $\mathrm{p}<0.05$ \\
\hline O. gratissimum+Crospovidone+Croscarmellose sodium (ABC) & 1 & 1740.25 & 1740.25 & 3353.7 & $\mathrm{p}<0.05$ \\
\hline Error & 14 & & 0.02 & - & - \\
\hline Total & 23 & - & - & - & - \\
\hline
\end{tabular}

*SD: Standard deviation from mean, $n=3, p<0.05$ indicates significance; $p>0.05$ indicates non-significance, d.f: Degree of freedom *S.S: Sum of square *M.S.S: Mean Sum of Squares, ANOVA: Analysis of variance. O. gratissimum: Ocimum gratissimum

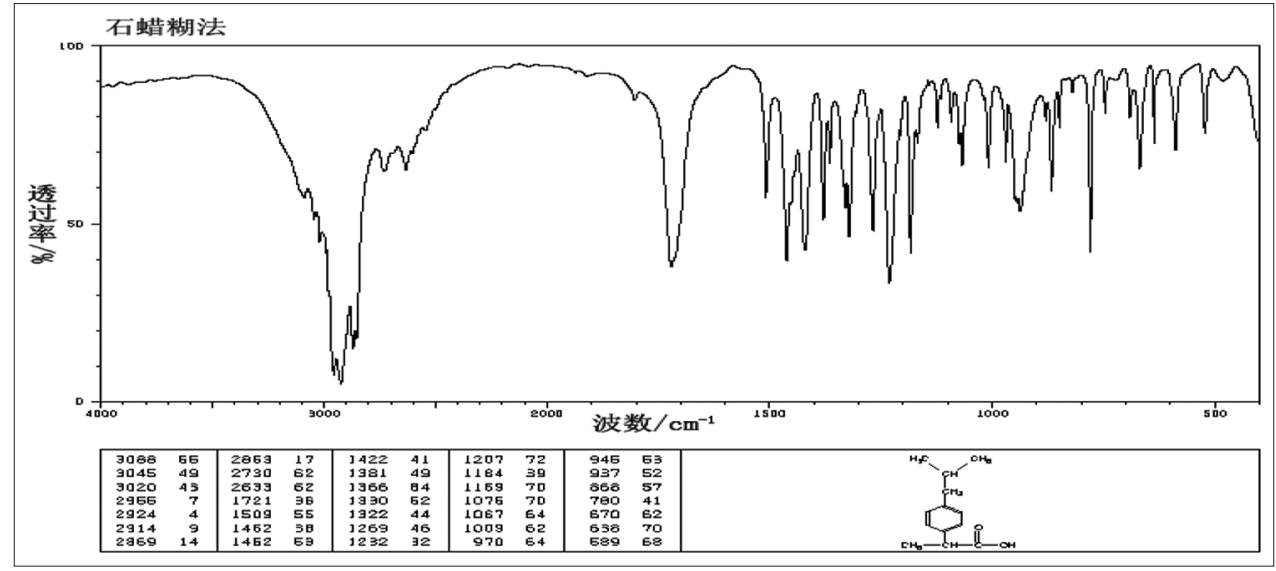

Fig. 1: Fourier transform infrared pure ibuprofen

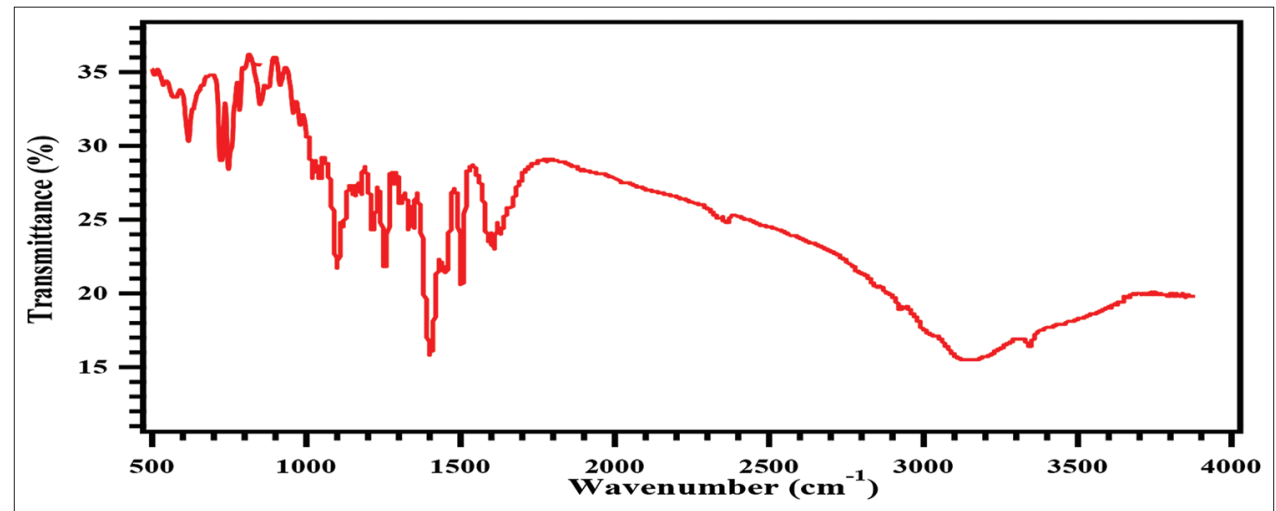

Fig. 2: Fourier transform infrared pure mucilage 


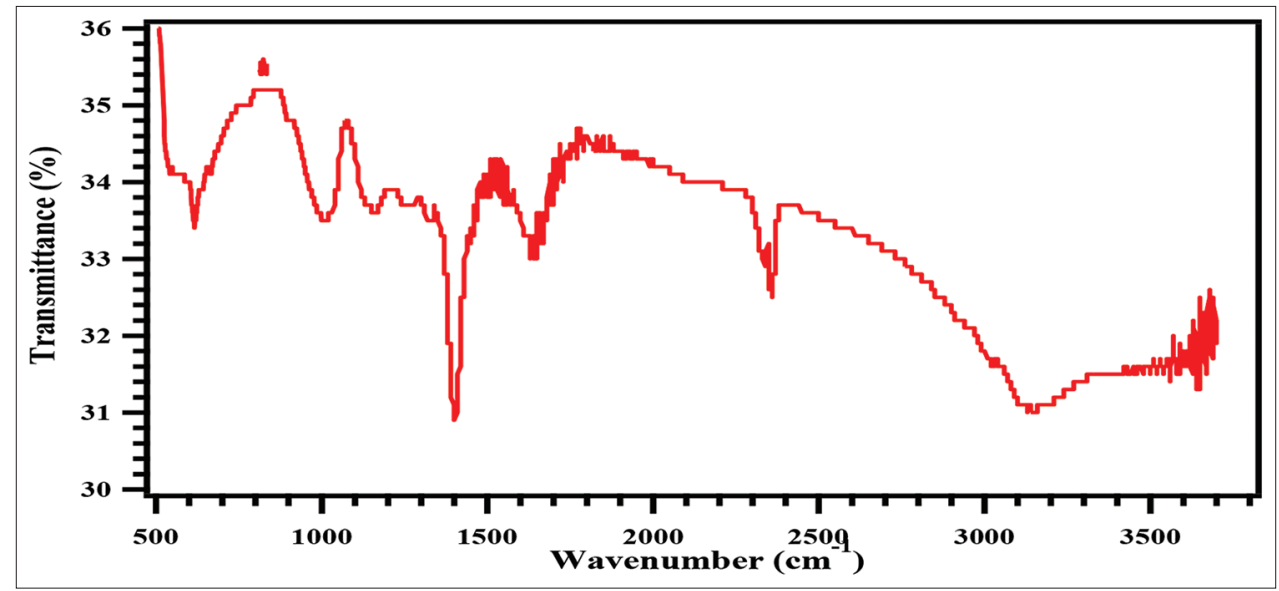

Fig. 3: Fourier transform infrared ibuprofen and mucilage

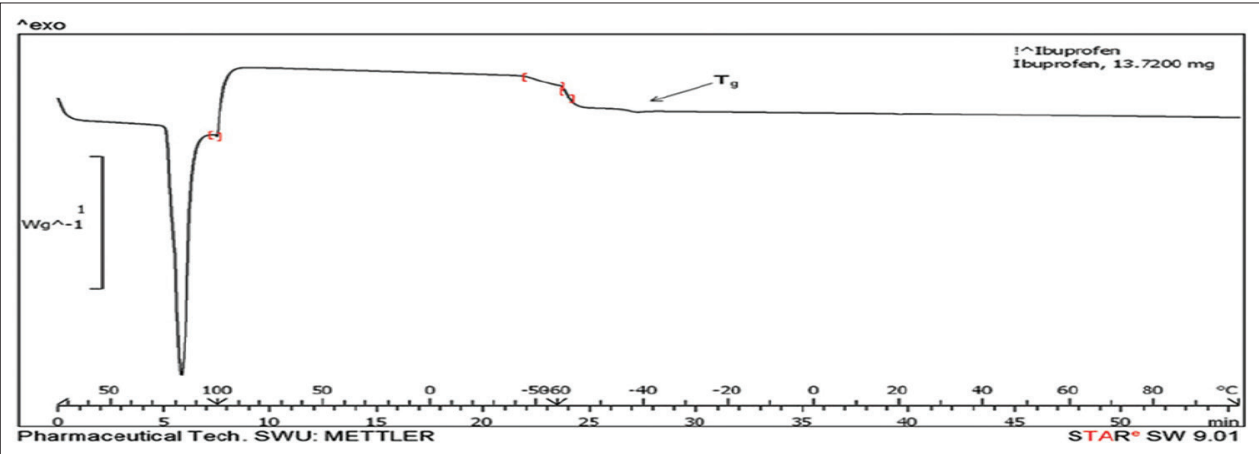

Fig. 4: Differential scanning calorimetry thermogram of mucilage and pure drug

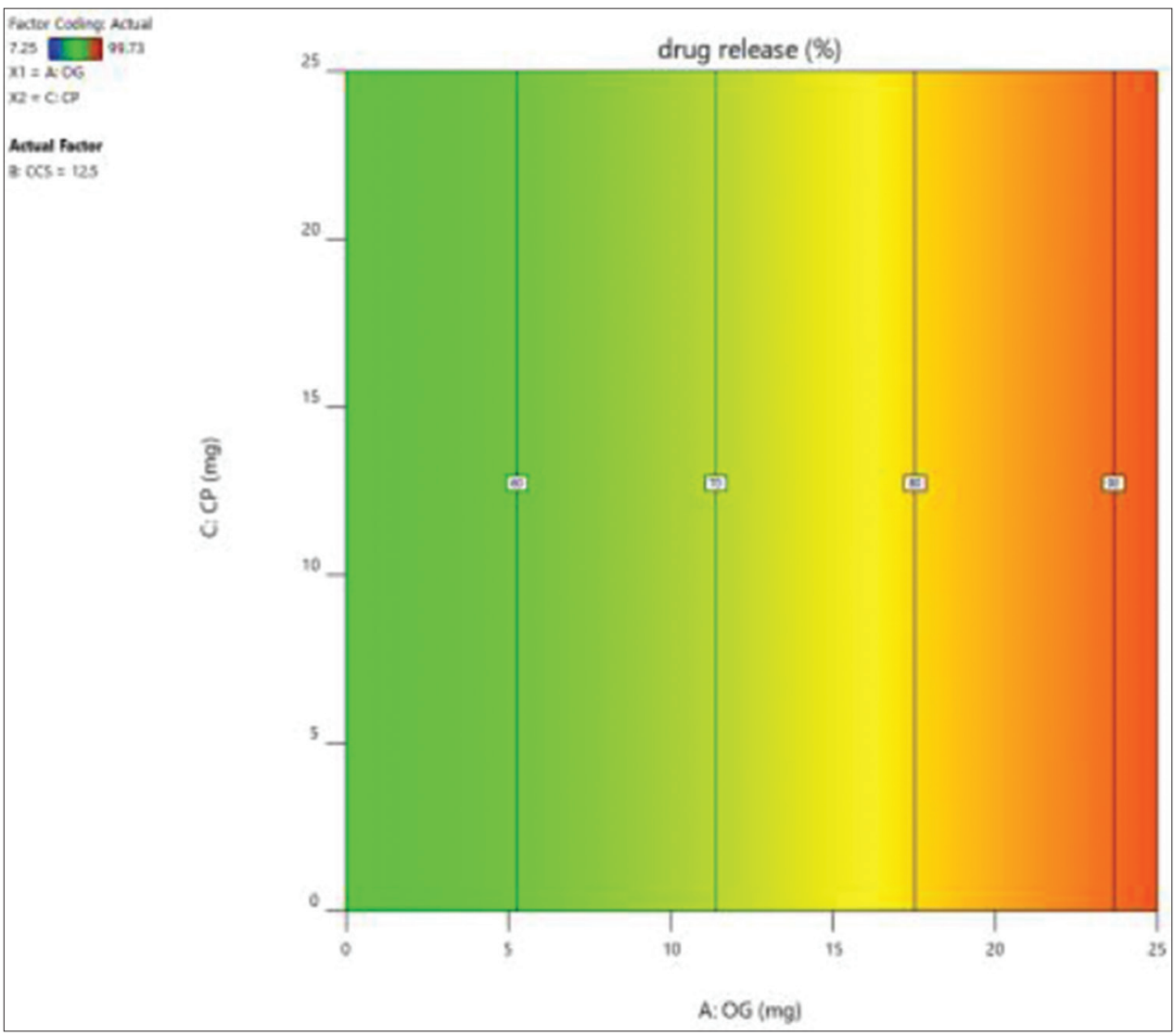

Fig. 5: Contour plot graph for with Ocimum gratissimum 


\section{Evaluation of tablets}

\section{Hardness}

The hardness of tablets from all batches was found to be in the range of $3.5 \pm 0.06 \mathrm{~kg} / \mathrm{cm}^{2}-3.9 \pm 0.07 \mathrm{~kg} / \mathrm{cm}^{2}$. All tablets were found hard enough so that they could easily withstand the handling and storage conditions without getting broken.

\section{Friability}

All the tablets exhibited acceptable friability, as none of the tested batches showed percentage friability that exceeded $1 \%$. The percent friability of all batches found in the range of $0.09 \%-0.19 \%$, indicating good mechanical resistance of tablets. Thus, it was proved that tablets could withstand the pressure, mechanical shocks during handling, transportation, storage, and manufacturing processes.

Drug content

The drug content of all the formulation batches was found to be between $98.05 \pm 0.31$ and $99.39 \pm 0.54$. Hence, it can be concluded that all the formulations are having an accurate amount of drug distributed uniformly in powder mass and followed acceptable limits as per IP [14], i.e., $85-115 \%$ of average content (Table 3).

\section{Disintegration studies}

In vitro disintegration time was done by the USP disintegration apparatus. The disintegration rate has a correlation with the water absorption capacity of disintegrate and the in vitro disintegration time was found between $1648 \pm 0.02$ and $29 \pm 0.57 \mathrm{~s}$. The outcomes were tabulated and data demonstrated in Table 3. All the formulation showed disintegration time of $<240 \mathrm{~s}$. It was found that the formulation F8 will show least disintegration time $30 \mathrm{~s}$ as compared to other formulation. The order for a disintegration time in the FDT was found to be $\mathrm{F} 8<\mathrm{F} 2<\mathrm{F} 7<\mathrm{F} 6<\mathrm{F} 3<\mathrm{F} 5<\mathrm{F} 4<\mathrm{F} 1$. The order of disintegration time may be due to the interaction and main effects of the super disintegrants used in the FDT.

\section{Water absorption ratio and wetting time}

The water absorption ratio founded from $20 \pm 0.01$ to $100 \pm 0.21 \mathrm{~s}$. This increased behavior due to the water takingtheability of superdisintegrants. The wetting time found was tabulated and data demonstrated in Table 3 and Figs. 5 and 6. It was found that the formulation F2 containing 5\% mucilage and 5\% croscarmellose sodium showed less wetting time, i.e., $30 \pm 0.39 \mathrm{~s}$ as compared to other formulations.

\section{In vitro dissolution studies}

Dissolution rate depends on the wetting time of the disintegrant; among all the formulations, F8 has less wetting time and has greater dissolution rate, and then this is the other conformance test for correct selection of desirable. In vitro dissolution studies of all the formulation were done and depicted in Fig. 7. In all formulations, F8 formulation was selected as the promising formulation containing

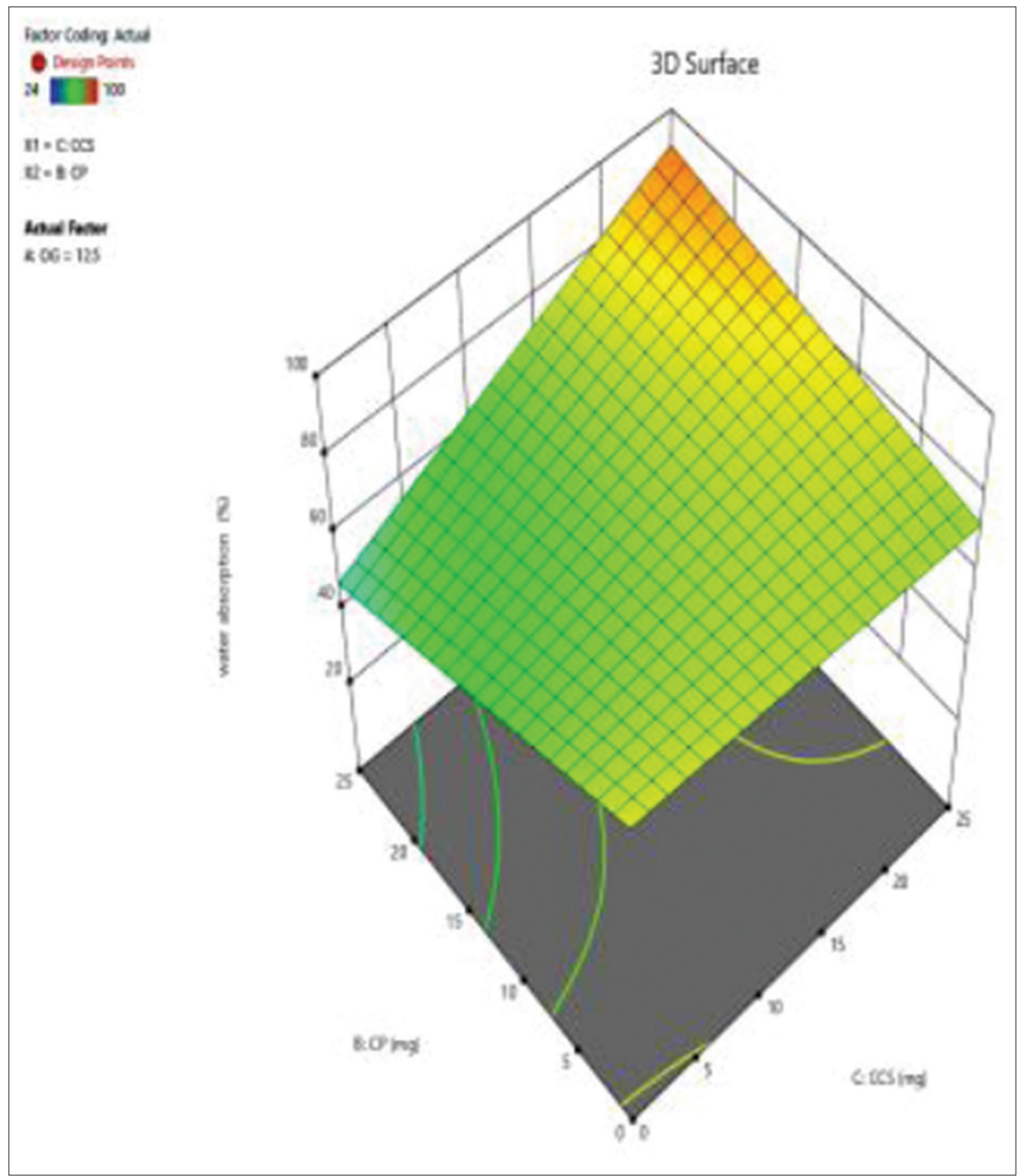

Fig. 6: Three dimensional graph for optimized formulation (F2) 


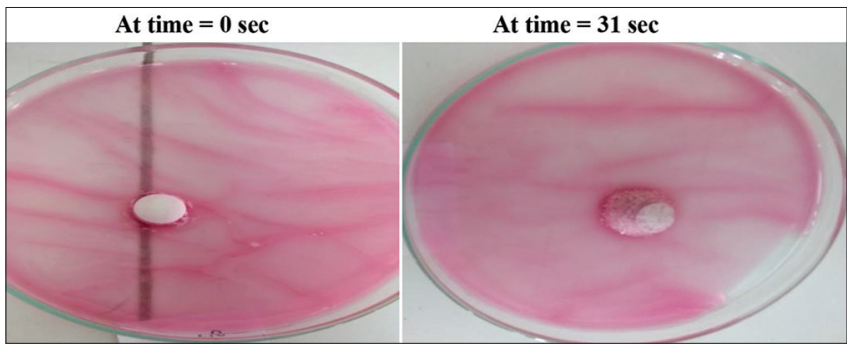

Fig. 7: Optimized formulation (F2) of ibuprofen fast-dissolving tablet

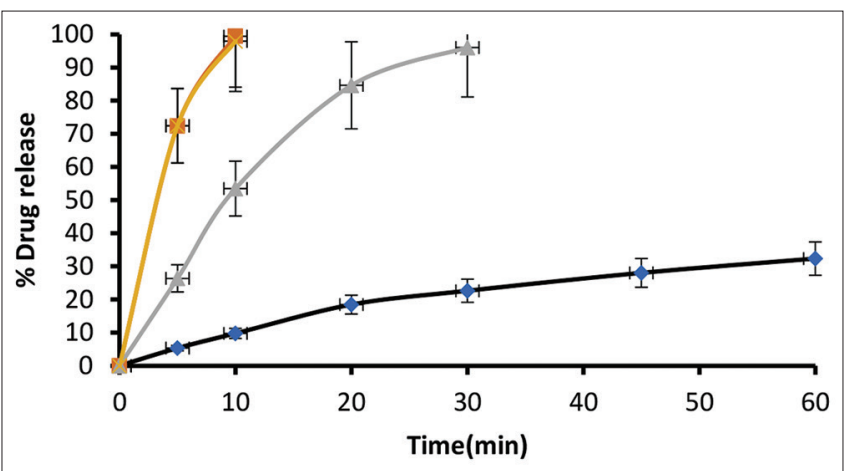

Fig. 8: Dissolution profiles of ibuprofen fast dissolving tablets prepared employing Ocimum gratissimum involving Mannitol as a diluents (F1-F4)

$5 \%$ o. gratissimum, $5 \%$ crospovidone, and $5 \%$ croscarmellose sodium with $99.15 \%$ release in 10 min which may be due to the interaction effect between the two super disintegrates, i.e., O. gratissimum, crospovidone, and croscarmellose sodium at a concentration of $5 \%$ each. The dissolution parameters of the formulation from F1 to F8, which were made by direct compression method are shown in Table 1. In all these cases, the percent dissolved in 5 minute (PD5) was more in F8, which consists of $5 \%$ O. gratissimum, $5 \%$ crospovidone, and $5 \%$ croscarmellose sodium. The same was in the case of DE5 \% (DE in $5 \mathrm{~min}$ ). The PD5 and DE5 \% revels that 0 . gratissimum was effective at $5 \%$, crospovidone at $5 \%$ along with $5 \%$ croscarmellose sodium when the formulations were made by direct compression using these superdisintegrants. From the results, it was concluded that $O$. gratissimum (new super disintegrate) could be used as a superdisintegrant in the formulation of FDT of ibuprofen. To evaluate the individual and combined effects of the three factors involved, FDTs were formulated employing selected combinations of the factors as per $2^{3}$ factorial design. The FDTs and release parameters (percent drug released in $5 \mathrm{~min}$ ) of the fast-dissolving formulated were analyzed as per the analysis of variance (ANOVA) of $2^{3}$ factorial design. ANOVA of percentage dissolved in 5 min (Table 4), ANOVA of water absorption (Table 5), indicated that the individual effects of 0 . gratissimum (A), crospovidone (B), and croscarmellose sodium (C) as well as the combined effects of $\mathrm{AB}, \mathrm{AC}, \mathrm{BC}$, and $\mathrm{ABC}$ factors, were significant $(p<0.05)$ on percentage dissolved in 5 min, wetting time, water absorption ratio, and DE in 5 min of ibuprofen FDT.

FDT formulated employing 0 . gratissimum (5\%), crospovidone (5\%), and croscarmellose sodium (5\%) as superdisintegrants exhibited in percentage dissolved in $5 \mathrm{~min}$, wetting time, water absorption ratio, and $\mathrm{DE}$ in $5 \mathrm{~min}$. Formulation F2 gave release of $99.15 \%$ in $10 \mathrm{~min}$ fulfilling the official specification, based on percentage dissolved in $5 \mathrm{~min}$, wetting time, water absorption ratio, and DE in 5 min. Formulation F2 is considered a good FDT formulations of ibuprofen, which was found to better than the ibuprofen FDT (Figs. 8 and 9).

Overall, natural novel mucilage was found to be a superdisintegrant which enhanced the DE when combined with crospovidone and

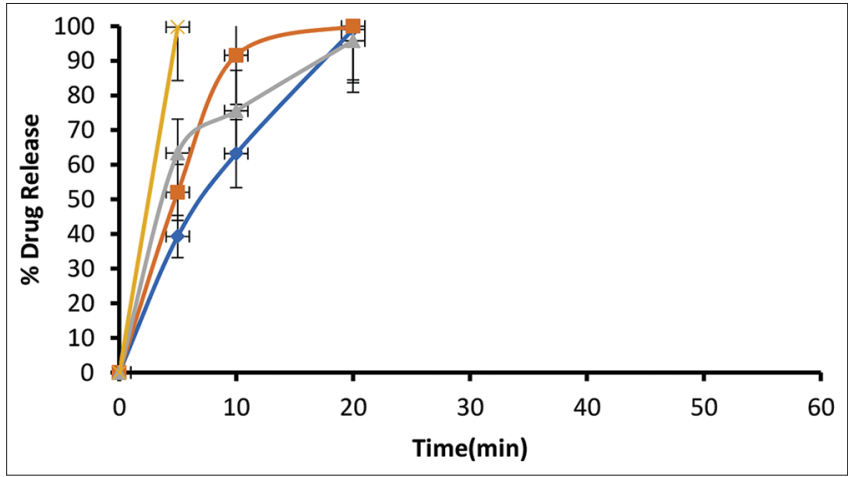

Fig. 9: Dissolution profiles of ibuprofen fast dissolving tablets prepared employing Ocimum gratissimum involving Mannitol as a diluents (F5-F8)

croscarmellose sodium, with the ibuprofen and hence it could be used in the formulation of FDT to provide immediate release of the contained drug within $1 \mathrm{~min}$.

\section{CONCLUSION}

FDTs of ibuprofen were formulated and optimized using $2^{3}$ factorial design. Three independent variables, that is, amount of $\mathrm{X}_{1}$ - amount of 0 . gratissimum, $\mathrm{X}_{2}$ - croscarmellose sodium, and $\mathrm{X}_{3}$ - crospovidone at three levels were selected on the basis of preliminary studies. The addition of superdisintegrant $O$. gratissimum mucilage leads to significant effect on disintegration characteristics as well as drug release. However, higher concentrations of mucilage had negative impact on drug release and disintegration. Addition of croscarmellose sodium and crospovidone leads to improved dissolution characteristics, not much affecting 10 International Scholarly Research Notices (ISRN) pharmaceutics disintegration time but higher concentration of o. gratissimum drug disintegration and drug release. The porous nature of tablets with swelling and wicking characteristics of mucilage along with increased drug solubility by ocimum gratissimum in combination lead to maximum drug release from fast dissolving tablets. The DesignExpert Software was used to optimize, and response surface plots and contour plots were drawn, and optimum formulations were selected by feasibility and grid searches. Polynomial mathematical models, generated for various response variables using multiple regression analysis, were found to be statistically significant $(p<0.05)$. Formulation F2 was selected by the Design-Expert Software which exhibited water absorption (97\%), and in vitro drug release (100\%) within $10 \mathrm{~min}$.

\section{ACKNOWLEDGMENT}

Authors are thankful to the Siddhartha Academy of General and Technical Education and principal of KVSR Siddhartha College of Pharmaceutical Sciences for providing facilities.

\section{AUTHOR'S CONTRIBUTIONS}

Dr. A. Bharathi the guarantor of this study has designed and supervised the experimental process. Mr. D. Chandra Sekhar Naik has carried out the experiments and analyzed the results. Dr M. V. Basaveswara Raohas contributed to preparation and revision of the manuscript.

\section{CONFLICTS OF INTEREST}

The authors declare that they have no conflicts of interest.

\section{REFERENCES}

1. Soni A, Rajoriya V, Kashaw V. Formulation development and evaluation of fast dissolving tablet of ramipril. Int J Pharm Pharm Sci 2015;7:127.

2. Dey P, Ghosh A. Wafers: An innovative advancement of orodispersible films. Int J Appl Pharm 2016;8:81-7.

3. Abdelbary G, Prinderre P, Eouani C, Joachim J, Reynier JP, Piccerelle P, et al. The preparation of orally disintegrating tablets using a hydrophilic 
waxy binder. Int J Pharm 2004;278:423-33.

4. Roy A. Orodispersible tablets: A review. Asian J Pharm Clin Res 2016;9:19.

5. Masih A, Kumar A, Singh S, Tiwari AK. Fast dissolving tablets: A review. Int J Cur Pharm Res 2017;9:8.

6. Biradar S, Bhagavati S, Kuppasad I. Fast dissolving drug delivery system: A brief overview. Int J Pharmacol 2005;4:2, 233.

7. Indurwade $\mathrm{NH}$, Rajyaguru $\mathrm{TH}$, Nakhat $\mathrm{PD}$. Noval approach-fast dissolving tablets. Indian Drug 2002;38:405.

8. The United States Pharmacopoeia 29, National Formulary 24, Asian Edition. Rockville, MD: USPC, Inc.; 2006. p. 1890.

9. Jacob S, Shirwaikar A, Joseph A, Srinivasan KK. Novel coprocessed excipient of mannitol and microcrystalline callous for preparing fast dissolving tablet of Glipizide. Indian J Pharm Sci 2007;69:633.

10. Hiremath JG, Shastry CS, Srinath MS. Pharmaceutical approaches of taste masking in oral dorage forms. Ind Drug 2004;41:253.

11. Abdelbary A, Elshafeey AH, Zidan G. Comparative effects of different cellulosic-based directly compressed orodispersible tablets on oral bioavailability of famotidine. Car Poly 2009;77:799.

12. Battu SK, Repka MA, Majumdar S, Madhusudan RY. Formulation and evaluation of rapidly disintegrating fenoverine tablets: Effect of superdisintegrants. Drug Dev Ind Pharm 2007;33:1225-32.

13. Goel H, Vora N, Rana V. A novel approach to optimize and formulate fast disintegrating tablets for nausea and vomiting. AAPS PharmSciTech 2008;9:774-81.

14. Jogala S, Ankathi L, Jarupula RN. Glimepiride fast disintegrating tablets: Formulation, evaluation and in vivo disintegration and dynamic studies. Int J Pharm Pharm Sci 2016;8:271.

15. Indian Pharmacopoeia Commission. Indian Pharmacopoeia.New Delhi: Indian Pharmacopoeia Commission; 2010. p. 218.

16. Kishore VS, Kumar DG, Sudheer B, Sandeep M. Design and development of fast dissolving tablets of ibuprofen. Res Rev Pharm Pharm Sci 2013;2:65.

17. Subrahmanyam CV. Text Book of Physical Pharmaceutics. $2^{\text {nd }}$ ed. New Delhi: Vallabh Prakashan; 2005. p. 210.

18. Lachman L, Lieberman A, Kinig JL. The Theory and Practice of Industrial Pharmacy. $2^{\text {nd }}$ ed. Mumbai: Varghese Publishing House; 1999. p. 67.

19. Govt. of India, Ministry of Health and Family Welfare. Indian Pharmacopoeia 2007. Vol. 1. Ghaziabad: The Indian Pharmacopoeia Commission; 2007. p. 177.

20. Padmaja B, Ramakrishna R, Goutham G. Formulation and evaluation of fast dissolving tablets of ranitidine hydrochloride. J Pharm Res 2015;9:165

21. Anupama K, Shelly K, Neena B. Formulation and evaluation of mouth dissolving tablets of oxcarbazepine. Int J Pharm Pharm Sci 2009;1:12. 